\title{
Motif Penggunaan Aplikasi Bigo Live Di Kalangan Mahasiswa Jurusan Ilmu Komunikasi Universitas Telkom
}

\author{
Gifthera Dwilestari ${ }^{1}$, Dini Salmiyah Fithrah Ali $^{2}$ \\ Prodi S1 Ilmu Komuikasi, Fakultas Komunikasi dan Bisnis, Universitas Telkom, Bandung
}

\begin{abstract}
ABSTRAK
Pengguna internet di Indonesia cukup tinggi diantara negara lainnya khususnya diantara negara-negara Asia Tenggara lainnya. Hampir seluruh pengguna internet di Indonesia adalah pengguna aktif sosial media. Salah satu aplikasi media sosial yang sedang tren saat ini adalah Bigo Live. Bigo Live merupakan aplikasi live video streaming, dimana penggunanya bisa berinteraksi secara realtime. Popularitas Bigo Live di kalangan pengguna media sosial cukup tinggi karena pada 6 bulan pertama sejak waktu rilisnya, aplikasi tersebut telah menduduki urutan ke-10 pada Top Charts untuk aplikasi gratis di Google Play Store dan urutan ke-4 Top Charts untuk aplikasi gratis kategori sosial. Keunikan Bigo Live lainnya yaitu Bigo Live memiliki nilai ekonomi dengan adanya sistem poin yang biasa disebut beans yang dapat ditukarkan dengan uang tunai apabila telah mencapai minimal 6.700 beans. Tujuan dilakukannya penelitian ini adalah menemukan motif yang mendorong penggunaan media sosial Bigo Live oleh mahasiswa jurusan Ilmu Komunikasi di Universitas Telkom. Penelitian ini dilakukan dengan menggunakan metode kualitatif kepada empat orang informan. Dari hasil penelitian ditemukan bahwa motif yang mendorong penggunaan media sosial Bigo Live oleh mahasiswa jurusan Ilmu Komunikasi Universitas Telkom ini relevan dengan teori motif penggunaan media yang diungkapkan oleh McQuail yaitu, motif informasi, motif identitas diri, motif integrasi dan interaksi sosial dan motif hiburan. Namun keempat motif tersebut tidak semuanya dimiliki informan, motif yang paling sering ditemukan adalah motif informasi, interaksi dan hiburan.
\end{abstract}

Kata-kata Kunci: Motif, Motif Penggunaan Media, Media Sosial, Bigo Live, Mahasiswa.

\section{Motif Of Using Bigo Live Application Among Students Of Communication Sciences Major In Telkom University}

\begin{abstract}
Internet users in Indonesia are quite high among other countries, especially among other Southeast Asian countries. Almost all internet users in Indonesia are active users of social media. One of the social media applications that are currently trending is Bigo Live. Bigo Live is a live video streaming application, where users can interact in realtime. The popularity of Bigo Live among social media users is quite high because in the first 6 months since its release time, the app has been ranked 10th on the Top Charts for free apps on the Google Play Store and the 4th Top Charts for free social category apps. The uniqueness of Bigo Live is that Bigo Live has an economic value with a point system commonly called 'beans' that can be redeemed for cash when it has reached a minimum of 6,700 beans. The purpose of this research is to find motives that encourages the use of social media Bigo Live by students majoring in Communication Studies at Telkom University. This research was conducted by using qualitative method to four informants. From the result of the research, it is found that the motives that encourage the use of social media Bigo Live by students of Telecommunication Science University are relevant to media use motive theory expressed by McQuail which are, information motive, self identity motive, integration and social interaction motive, and entertainment motive. But the four motifs are not all owned by the informants, the motives that most often found was information, interaction and entertainment motives.
\end{abstract}

Keywords: Motive, Motive of Media Usage, Social Media, Bigo Live, Student.

Korespondensi: Gifthera Dwilestari. Telkom University. Jl. Telekomunikasi, Jl. Terusan Buah Batu No.01, Sukapura, Dayeuhkolot, Bandung, Jawa Barat 40257. Email: ggdwilestari@ gmail.com

ISSN: 2548-3242 (cetak), eISSN: 2549-0079 Website: http://jurnal.unpad.ac.id/jkk 


\section{PENDAHULUAN}

Perkembangan teknologi khususnya internet membawa pengaruh besar dalam perubahan media komunikasi. Saat ini berbagai negara di seluruh dunia telah dapat mengakses internet dan menggunakan internet sebagai media komunikasi seharihari. Kemajuan era komunikasi ini tentu saja dimanfaatkan pula oleh masyarakat Indonesia yang jumlah pengguna internetnya tinggi. Hasil survey yang dilakukan oleh Asosiasi Penyelenggara Jaringan Internet Indonesia (APJII) mengungkap bahwa lebih dari setengah penduduk Indonesia kini telah terhubung ke internet. Survei yang dilakukan sepanjang 2016 itu menemukan bahwa 132,7 juta orang Indonesia telah terhubung ke internet. Adapun total penduduk Indonesia sendiri sebanyak 256,2 juta orang. (Widiartanto, 2016)

Dari data statistik yang diperoleh dari sebuah agensi marketing sosial, We Are Social, digambarkan bahwa pada bulan Januari 2016 jumlah pengguna internet aktif di Indonesia mencapai 88,1 juta pengguna dan 66 jutanya tergolong ke dalam active mobile social user atau pengguna aktif dalam menggunakan media sosial melalui perangkat mobile (Rosabel, 2016). Media sosial menurut Nasrullah (2015:11) adalah medium di internet yang memungkinkan pengguna merepresentasikan dirinya maupun berinteraksi, bekerjasama, berbagi, berkomunikasi dengan pengguna lain, dan membentuk ikatan sosial secara virtual.

Beberapa aplikasi media sosial yang populer digunakan di Indonesia diantaranya adalah Facebook, Instagram, Path, BBM, Line dan Snapchat. Pada tahun 2016 telah hadir satu aplikasi media sosial baru yaitu Bigo Live. Bigo Live sendiri merupakan aplikasi media sosial yang dikembangkan oleh perusahaan asal Singapura, Bigo Technology Pte. Ltd. yang baru dirilis pada bulan Maret 2016. Aplikasi ini dapat diunduh secara gratis oleh para pengguna android pada Google Play Store dan juga pengguna $i O S$ di Apple Store.

Bigo Live merupakan aplikasi live video streaming, dimana penggunanya bisa berinteraksi secara realtime. Dengan platform mobile streaming penggunanya bisa menggunakan aplikasi tersebut dimanapun dan kapanpun menggunakan perangkat mobile. Pengguna Bigo Live sendiri terbagi kedalam 2 jenis peran yaitu broadcaster dan viewer. Broadcaster adalah pengguna yang melakukan siaran live sedangkan viewer adalah pengguna yang menonton siaran. Broadcaster Bigo Live disebut juga Bigo Host, Bigo Host ini ada yang merupakan Official Bigo Host yaitu orang yang dikontrak langsung oleh perusahaan Bigo maupun broadcaster biasa yaitu para pengguna Bigo Live yang melakukan siaran sesuai dengan keinginan mereka. 
Aplikasi Bigo Live memiliki Live dapat menghasilkan uang dengan beberapa fitur antara lain Live Broadcasting, melakukan siaran melalui aplikasi Bigo Live Real-time Interaction, Follow Broadcaster, yang dapat diunduh dan digunakan secara Virtual Gifts, Mobile Streaming dan Bonus. gratis ini. Semakin banyak orang yang Tujuan utama developers mengembangkan menonton siaran broadcaster tersebut maka aplikasi Bigo Live adalah sebagai media bagi para broadcaster untuk menampilkan bakat mereka secara langsung misalnya menyanyi, menari, membuat tutorial, maupun sekedar melakukan live chat. Namun pada praktiknya Bigo Live banyak disalahgunakan untuk halhal yang tidak baik seperti pembajakan film hingga menayangkan hal-hal berbau seksual. Meskipun banyak pemberitaan negatif tentang penyalahgunaan aplikasi Bigo Live hingga sempat terjadi pemblokiran sementara aplikasi tersebut oleh Kominfo, sampai saat ini masih banyak pengguna sosial media di Indonesia yang lebih memilih Bigo Live sebagai media komunikasi.

Popularitas Bigo Live di kalangan pengguna media sosial cukup tinggi karena pada 6 bulan pertama sejak waktu rilisnya, aplikasi tersebut telah menduduki urutan ke10 pada Top Charts untuk aplikasi gratis di Google Play Store dan urutan ke-4 Top Charts untuk aplikasi gratis kategori sosial. Mengikuti popularitas aplikasinya, istilah Bigo Live kini sedang popular di kalangan pengguna internet dan Bandung adalah kota yang menempati urutan pertama dalam survey tren Bigo Live di Jawa Barat. Dilansir dari merdeka.com yang menjadikan Bigo Live populer adalah karena broadcaster Bigo semakin banyak pula uang yang bisa didapatkannya (Tsana, 2016). Setiap kali broadcaster melakukan siaran, penonton berkesempatan memberikan virtual gift, setiap gift memiliki nilai masing-masing yang disebut diamonds atau beans. Nilai 3 diamonds sama dengan 10 beans dan setiap 6.700 beans dapat ditukarkan dengan uang senilai $\operatorname{Rp} 2.000 .000$.

Menurut hasil survei Asosiasi Penyelenggara Jasa Internet Indonesia (APJII) yang bekerja sama dengan Pusat Kajian dan Komunikasi Universitas Indonesia (Puskakom UI), di Indonesia pada tahun 2014 mayoritas pengguna internet di Indonesia adalah berusia 18-25 tahun. Persentasenya mencapai 49,0 persen. Artinya, segmen pengguna internet terbesar di Indonesia adalah mereka yang termasuk dalam kategori digital natives. Digital natives adalah generasi yang lahir setelah tahun 1980, ketika internet mulai digunakan masyarakat secara luas.

Penelitian ini dilakukan kepada mahasiswa yang mendalami bidang ilmu komunikasi di jurusan Ilmu Komunikasi, fakultas Komunikasi dan Bisnis Universitas Telkom. Devito (dalam Effendy, 2003:14) mengatakan bahwa komunikologi adalah 
suatu studi tentang ilmu komunikasi, secara khusus subseksinya berkaitan dengan komunikasi oleh dan di antara manusiamanusia. Effendy (2003:29) juga mengatakan bahwa semakin peliknya antar manusia dan semakin pentingnya studi terhadap komunikasi itu disebabkan teknologi, khususnya teknologi komunikasi yang semakin lama semakin canggih. Oleh karena itu mahasiswa jurusan Ilmu Komunikasi yang mempelajari mengenai komunikasi antar manusia sudah seharusnya lebih peka terhadap perkembangan media komunikasi yang semakin dinamis.

Penelitian sendiri dilakukan di Universitas Telkom dengan pertimbangan bahwa Universitas Telkom merupakan sebuah perguruan tinggi swasta berbasis ICT di Bandung mencanangkan akan menjadi perguruan tinggi berkelas internasional yang unggul di bidang informasi dan komunikasi pada tahun 2017. Universitas Telkom yang baru berusia 3 tahun telah meraih akreditasi A pada penghujung tahun 2016. Kementerian Riset, Teknologi dan Pendidikan Tinggi (Kemenristekdikti) memberikan akreditasi tersebut melalui Badan Akreditasi Nasional Perguruan Tinggi (BAN PT) dalam Keputusan Nomor 3125/SK/BAN-PT/Akred/PT/XII/2016.

Maka berdasarkan uraian di atas penulis ingin mengetahui apakah mahasiswa Ilmu Komunikasi Universitas Telkom sudah peka terhadap hadirnya media komunikasi yang baru dan juga motif mahasiswa dalam menggunakan media tersebut. Maka dari itu penulis melakukan penelitian yang berjudul "Motif Penggunaan Aplikasi Media Sosial Bigo Live di Kalangan Mahasiswa Ilmu Komunikasi Universitas Telkom”.

\section{METODE PENELITIAN}

Dalam melakukan penelitian ini, peneliti penggunakan paradigma konstruktivis. Paradigma konstruktivis melihat suatu realita dibentuk oleh berbagai macam latar belakang sebagai bentuk konstruksi realita tersebut. Realita yang dijadikan sebagai objek penelitian merupakan suatu tindakan sosial oleh actor sosial. Paradigma konstruktivis sifatnya kualitatif, peneliti memasukan nilai-nilai pendapat ke dalam penelitiannya. Penelitian dengan paradigm ini sifatnya subjektif. Paradigma konstruktivis bertujuan untuk memahami apa yang menjadi konstruksi suatu realita. Oleh karena itu peneliti harus dapat mengetahui faktor apa saja yang mendorong suatu realita dapat terjadi dan menjelaskan bagaimana factor-faktor itu merekonstruksi realita tersebut. (Pujileksono, 2015:28). Dalam melakukan penelitian ini peneliti menggunakan metode kualitatif sebagai pedoman dalam melakukan penelitian. Bogdan dan Taylor (dalam Moleong, 2014:4) mendefinisikan metode kualitatif sebagai prosedur penelitian yang menghasilkan data deskriptif berupa kata- 
kata tertulis atau lisan dari orang-orang dan perilaku yang dapat diamati. Penelitian kualitatif merupakan penelitian yang bermaksud untuk memahami fenomena tentang apa yang dialami oleh subjek penelitian contohnya seperti perilaku, persepsi, motivasi, tindakan dan lainnya, secara holistik, dan dengan cara deskripsi dalam bentuk kata-kata dan bahasa, pada suatu konteks khusus yang alamiah dan dengan memanfaatkan berbagai metode ilmiah (Moleong, 2014:6). Dengan menggunakan metode kualitatif penulis berusaha menghasilkan data deskriptif mengenai motif yang mendorong penggunaan aplikasi Bigo Live dikalangan mahasiswa jurusan Ilmu Komunikasi di Universitas Telkom. Dengan metode ini, seorang peneliti hanya perlu menggambarkan realitas objek yang diteliti secara baik, utuh, jelas dan sesuai dengan fakta yang tampak (dilihat dan didengar). Oleh karena itu, peneliti menggunakan metode deskriptif untuk menggambarkan hasil penelitian yang dilakukan sehingga peneliti dapat memaparkan hasil penelitian berdasarkan realitas yang ada secara jelas.

Dalam mengumpulkan informasi mengenai penelitian yang dilakukan, penulis tentu membutuhkan objek sebagai sumber informasi. Subjek penelitan menurut Idrus (2009:91) adalah individu, benda, atau organisme yang dijadikan sumber informasi yang dibutuhkan dalam pengumpulan data penelitian. Dalam penelitian ini subjek penelitian penulis adalah yang memiliki kriteria sebagai berikut:

1) Mahasiswa aktif jurusan Ilmu Komunikasi Universitas Telkom

2) Berusia minimal 18 tahun

3) Telah menggunakan aplikasi Bigo Live minimal 6 bulan

4) Mengetahui fitur-fitur yang ada pada aplikasi Bigo Live.

5) Bersedia menjadi informan penelitian dan bersedia hasilnya dipublikasikan.

Berdasarkan kriteria tersebut peneliti telah menentukan empat orang informan yang sesuai menjadi seumber informasi dalam penelitian ini. Objek penelitian pada penelitian ini adalah motif penggunaan media, tepatnya adalah motif yang mendorong subjek penelitian dalam menggunakan aplikasi media sosial Bigo Live.

Muhammad Idrus

(2009:62)

menjelaskan bahwa data penelitian kualitatif diperoleh dari hal-hal yang diamati, didengar, dirasa, dan dipikirkan oleh peneliti. Informasi-informasi yang dihimpun oleh peneliti harus selalu terkait dengan fokus penelitian. Biasanya data tersebut berupa rekaman wawancara yang kemudian harus ditranskripkan dalam bentuk narasi. Sugiyono (dalam Ibrahim 2015:80) menyebutkan pengumpulan data kualitatif dapat dilakukan dengan empat teknik yaitu observasi, wawancara, dokumentasi dan 
gabungan/triangulasi. Dalam penelitian ini, peneliti menggunakan tiga teknik pengumpulan data yaitu observasi, wawancara dan dokumentasi.

Susan Steinbeck menyebutkan bahwa dengan wawancara peneliti dapat mengetahui hal-hal yang lebih mendalam tentang partisipan dalam menginterpretasikan situasi dan fenomena yang terjadi, dimana hal itu tidak bisa didapatkan dengan teknik lain, termasuk observasi (dalam Ibrahim 2015:88). Wawancara tak terstruktur dalam penelitian kualitatif digunakan oleh peneliti yang memulai aktivitas pengumpulan data sebagai orang yang hendak belajar, sebab peneliti belum mengetahui secara pasti data yang akan diperoleh. Karena itu, penelitian dengan wawancara tak terstruktur lebih bersifat mendengarkan apa yang dibicarakan atau diceritakan oleh informan (Ibrahim,2015:90) Dalam penelitian ini pertama penulis menggunakan teknik wawancara untuk mengungkap lebih jauh maksud dan tujuan penggunaan Bigo Live yang dilakukan oleh informan penelitian.

Kedua yaitu observasi atau yang disebut juga pengamatan menurut Sukmadinata (2012:220) adalah suatu teknik atau cara mengumpulkan data dengan jalan mengadakan pegamatan terhadap kegiatan yang sedang berlangsung. Pengamatan dapat diklasifikasikan atas pengamatan melalui cara berperan serta dan yang tidak berperan serta. Pada pengamatan tanpa peran serta pengamat hanya melakukan satu fungsi, yaitu mengadakan pengamatan. Pengamat berperan serta melakukan dua peranan sekaligus, yaitu sebagai pengamat dan sekaligus menjadi anggota resmi dari kelompok yang diamatinya (Meolong 2012:176). Dalam penelitian ini peneliti melakukan pengamatan peran serta, dimana peneliti terlibat langsung dalam menggunakan aplikasi Bigo Live dengan tujuan agar peneliti dapat mengamati secara langsung aktivitas yang dilakukan informan ketika menggunakan aplikasi tersebut.

Ketiga adalah melalui dokumentasi. Menurut Ridjal, yang dimaksud dokumen adalah rekaman peristiwa yang lebih dekat dengan percakapan, menyangkut persoalan pribadi, dan memerlukan interpretasi. Dalam penelitian ini peneliti menggunakan dokumentasi pribadi informan sebagai salah satu sumber data penelitian. Dokumen pribadi adalah catatan yang dibuat seseorang secara tertulis tentang pengalaman, tindakan dan kepercayaannya.

Untuk mengetahui keabsahan data penulis melakukan pencecekan melalui teknik triangulasi. Triangulasi adalah teknik pemeriksaan keabsahan data yang memanfaatkan sesuatu yang lain. Triangulasi teknik atau metode dilakukan dengan cara membandingkan data yang dihasilkan dari beberapa teknik yang beda, yang digunakan dalam penelitian. Contohnya dengan membandingkan data hasil observasi dengan 
data hasil wawancara, data hasil wawancara dengan data dokumentasi, atau data dokumentsi dengan data hasil observasi. Peneliti membandingkan data hasil wawancara, observasi dan dokumentasi dalam memeriksa keabsahan data. Dengan cara ini peneliti dapat menemukan data yang absah dan dapat dipercaya diantara kemungkinan kontradiksi data dan semacamnya.

Selain itu pengecekan juga dilakukan melalui kecukupan referensi. Kecukupan referensi yang dimaksud adalah tersedianya berbagai sumber yang dapat digunakan untuk menjelaskan data-data suatu penelitian. Artinya bahwa, peneliti memiliki banyak sumber yang data digunakan untuk menjelaskan data-data penelitiannya, baik sumber manusianya (sumber data), maupun sumber bahan berupa buku-buku rujukan. Ketersediaan sumber rujukan akan sangat menentukan derajat keterpercayaan sebuah hasil penelitian. (Ibrahim 2015: 127). Peneliti menggunakan referensi dari buku, jurnal ilmiah serta publikasi-publikasi lainnya sehingga peneliti dapat menjelaskan dengan baik data yang dihasilkan dari penelitian yang telah dilakukan.

\section{HASIL DAN PEMBAHASAN}

Berdasarkan hasil penelitian, peneliti menemukan jawaban apa yang menjadi motif dalam penggunaan sosial media. Bigo Live.
Motif yang peneliti temukan dari hasil penelitian tersebut adalah:

1. Adanya kebutuhan untuk mencari informasi mengenai Bigo Live itu sendiri serta mencari informasi lain dengan menggunakan Bigo Live

2. Adanya kebutuhan untuk mengekspresikan diri

3. Adanya kebutuhan untuk melakukan interaksi sosial dan membangun hubungan pertemanan dengan sesama pengguna Bigo Live.

4. Adanya kebutuhan untuk mendapatkan hiburan ketika memiliki waktu luang dan melepaskan kejenuhan atau rasa bosan.

Dari data yang telah didapatkan dari informan, ada motif informasi yang dimiliki informan dalam menggunakan Bigo Live. Bigo Live yang baru dirilis tahun kemarin ini menarik minat informan untuk mengetahui lebih jauh cara kerja media sosial tersebut sehingga akhirnya informan memutuskan untuk mencoba menggunakan aplikasi Bigo Live. Dalam teori mengenai motif penggunaan media McQuail (1987: 72) disebutkan bahwa motif informasi yaitu 1) Mencari berita tentang peristiwa dan kondisi yang berkaitan dengan lingkungan terdekat, masyarakat dan dunia, 2) Mencari bimbingan menyangkut berbaggai masalah praktis, pendapat, dan hal-hal yang berkaitan dengan penentuan pilihan, 3) Memuaskan rasa ingin tahu dan minat umum, dan 4) Memperoleh 
rasa damai melalui penambahan pengetahuan. Dengan menggunakan Bigo Live kebutuhan akan informasi para informan mengenai media sosial tersebut akan didapatkannya secara langsung sehingga rasa ingin tahu dan minat umum informan bisa terpenuhi.

Informasi merupakan pesan yang disampaikan dalam proses komunikasi. Dalam komunikasi, pesan dapat berupa katakata atau tulisan, tiruan, gambaran, atau perantara lain. Wirsanto (dalam Nurjaman dan Umam,2008) mengatakan ada tiga bentuk berita (pesan), yaitu: Audible, yaitu dapat didengar, baik secara langsung maupun tidak langsung; Visual, yaitu dapat dilihat; dan audio-visual, yaitu dapat didengar dan dilihat. Bentuk pesan atau informasi yang terdapat dalam Bigo Live adalah ketigatiganya. Audible berupa kata-kata yang diungkapkan secara langsung dalam siaran, Visual berupa kata-kata yang tersampaikan melalui fitur komentar atau chatting, atau bisa juga berupa gift, serta bentuk audiovisual berupa video streaming dan video call.

Menggunakan Bigo Live juga memungkinkan informan untuk dapat mencari informasi lain yang dibutuhkannya, namun informasi yang banyak dicari oleh para informan rupanya bukanlah informasi yang bermanfaat bagi banyak orang seperti berita mengenai peristiwa yang terjadi di sekitar, maupun pengetahuan umum yang perlu diketahui oleh masyarakat. Informasi yang dicari oleh para informan melalui penggunaan aplikasi Bigo Live umumnya merupakan informasi personal mengenai individual. Biasanya para pengguna Bigo Live ini melakukan pencarian informasi atau menghimpun informasi mengenai individu yang menarik bagi dirinya sendiri.

Timbulnya motif informasi pengguna dalam penggunaan Bigo Live ini dikarenakan pencarian informasi di Bigo Live sangat mudah. Dalam mencari informasi pengguna hanya tinggal menonton siaran live individu yang diminati kemudian informan akan mencari informasi yang diinginkan dengan menanyakan secara langsung ataupun mendengarkan jawabanjawaban dari pertanyaan yang diajukan oleh penonton lainnya.

Pencarian informasi tersebut merupakan salah satu pemuasan pengguna akan kebutuhan informasi. Informan mengatakan bahwa ia puas dapat menemukan informasi yang ingin diketahuinya melalui penggunaan aplikasi Bigo Live ini. Sehingga dapat dikatakan bahwa penggunaan aplikasi Bigo Live dapat memenuhi kebutuhan informasi penggunanya.

Perilaku pencarian informasi dan ditemukannya informasi dalam Bigo Live oleh informan menunjukan bahwa Bigo Live ini memenuhi salah satu karakteristik media sosial yang diungkapkan oleh Nasrullah 
(2015) yaitu informasi. Karakteristik informasi ini menjelaskan bahwa di media sosial informasi menjadi komoditas bernilai yang diproduksi, dipertukarkan dan dikonsumsi oleh para pengguna media sosial.

Selain itu menurut Senova (2016) "media sosial adalah salah satu media yang cukup berpengaruh untuk mempermudah orang-orang untuk berinteraksi satu sama lain, selain sifatnya yang praktis dan mudah diakses oleh penggunanya, media sosial juga sebagai tempat menyebarkan informasi kepada masyarakat secara luas. Informasi yang disebarkan melalui sosial media akan lebih mudah diterima oleh pengguna yang sudah memiliki kecakapan dalam mengakses informasi melalui berbagai jenis media sosial." Hal ini menjelaskan bahwa media sosial Bigo Live ini dapat dijadikan sumber informasi oleh penggunanya dengan adanya kemudahan akses pengguna Bigo Live dalam mencari dan mendapatkan informasi di media sosial tersebut.

Dari hasil penelitian juga ditemukan motif identitas diri dalam menggunakan Bigo Live. Stuart dan Sundeen (1991:378) mengatakan bahwa identitas diri adalah kesadaran akan diri sendiri yang bersumber dari observasi dan penilaian, yang merupakan sintesa dari semua aspek konsep diri sebagai suatu kesatuan yang utuh.

McQuail mengatakan motif identitas diri yaitu 1) Menemukan nilai-nilai penunjang pribadi, 2) Menemukan model perilaku, 3) Mengidentifikasikan diri dengan nilai-nilai lain (dalam media), dan 4) Meningkatkan pemahaman tentang diri sendiri (1987:72). Dalam menggunakan Bigo Live, rupanya pengguna dapat meningkatkan pemahaman mengenai dirinya sendiri. Perilaku tersebut ditunjukan ketika pengguna secara leluasa bercerita mengenai dirinya melalui siaran Bigo Live. Siaran Bigo Live yang dapat ditonton oleh siapa saja secara acak menunjukan bahwa pengguna Bigo Live dengan nyaman membuka dirinya kepada publik dan juga terbuka akan komentar-komentar yang diterimanya.

Bigo Live sebagai media sosial memiliki karakteristik user-generated content artinya konten-konten yang ada pada Bigo Live diproduksi oleh penggunanya sendiri. Oleh sebab itu dalam menggunakan Bigo Live pengguna dapat membuat berbagai konten yang dianggap sesuai dengan dirinya sendiri ataupun yang dianggap menarik untuk banyak orang. Namun Bigo Live sebagai media sosial juga tentunya memiliki karakteristik simulation of society dimana media sosial memiliki aturanaturan dan etika yang harus dipatuhi para penggunanya. Bigo Live memang aplikasi yang dibuat agar para penggunanya bebas menunjukan minat dan bakat penggunanya namun tentu saja ada aturan-aturan yang diberikan oleh Bigo Live agar penggunanya tidak melanggar batasan norma-norma sosial maupun norma hukum. Untuk mengatasi hal 
tersebut, Bigo Live memberikan kebijakan berupa ban atau larangan kepada para pelanggarnya. Pengguna yang melanggar kebijakan akan dilarang menggunakan akun Bigo Live-nya selama beberapa waktu bahkan dan jika pengguna melakukan pelanggaran secara terus-menerus maka akan dilakukan pemblokiran sehinga akun pengguna tersebut tidak bias digunakan secara permanen.

Sebagai media komunikasi, Bigo Live tentu memfasilitasi penggunanya untuk saling berinteraksi melalui bermacam cara seperti dengan adanya fitur chatting, komentar, video call. Fitur-fitur tersebut memudahkan pengguna Bigo Live untuk berinteraksi secara personal juga memungkinkan pengguna membangun hubungan pertemanan. Interaksi sosial menurut Maryati dan Suryawati (2003:194) adalah kontak atau hubungan timbal balik atau interstimulasi dan respon antar individu, antar kelompok atau antar individu dan kelompok interaksi.

Interaksi yang bisa dilakukan melalui Bigo Live beragam, yang paling utama adalah video streaming yang merupakan fungsi utama aplikasi tersebut. Video streaming ini memungkinkan pengguna Bigo Live melakukan interaksi dari individu ke kelompok dan karena interaksi dilakukan secara real-time maka sangat memungkinkan komunikasi tersebut mendapatkan timbal balik secara langsung.
Dalam aspek dalam komunikasi cyber yang dijelaskan oleh Smith (dalam Nasrullah, 2014:80) dikatakan bahwa interaksi yang dilakukan melalui media cyber bisa terjadi dalam waktu yang sama (synchronous) dan juga bisa berbeda (asynchronous). Interaksi secara synchronous ditunjukan ketika menonton maupun melangsungkan siaran live, ketika memberi komentar dan gift serta ketika melakukan video call. Interaksi secara ansynchronous dilakukan jika pengguna Bigo Live menggunakan fitur chatting .

Motif interaksi sosial merupakan motif yang berkaitan dengan dorongan individu untuk berinteraksi dengan orang lain, dorongan untuk memperoleh pengetahuan akan empati sosial, dorongan untuk mempertahankan norma-norma sosial, dorongan untuk membantu individu dalam menjalankan peran sosial (McQuail, 1983:82). Dalam Morrisan (2010:70) juga dijelaskan bahwa pada umumnya setiap individu memiliki kebutuhan mendasar terhadap interaksi sosial. Berdasarkan pengalamannya seseorang mengharapkan bahwa konsumsi atau penggunaan media tertentu, akan memberikan sejumlah pemenuhan bagi kebutuhannya. Penggunaan Bigo Live dapat memenuhi kebutuhan akan interaksi sosial yang dimiliki oleh para informan terutama dengan adanya fitur-fitur pendukung seperti chatting, komentar dan juga video call. 
Informan sebagai individu yang membutuhkan interaksi sosial memanfaatkan Bigo Live untuk membangun mencari teman baru. Melalui Bigo Live informan dapat terhubung dan berkenalan secara online dengan orang-orang yang ditemuinya dalam aplikasi tersebut kemudian ia dapat memutuskan untuk melanjutkan pertemuan yang awalnya dilakukan secara online tersebut ke pertemuan secara langsung atau bertatap muka. Hal ini menunjukan bahwa Bigo Live memiliki kemampuan untuk memuaskan kebutuhan manusia akan interaksi sosial dimana para penggunanya dapat berinteraksi dan menjalin pertemanan yang lebih lanjut.

Kemampuan Bigo Live dalam membantu penggunanya untuk menjalin pertemanan juga menunjukan bahwa Bigo Live memenuhi salah satu karakteristik sosial media lainnya, yaitu jaringan. Nasrullah (2015) mengatakan bahwa media sosial membentuk jaringan sosial antar penggunanya karena media sosial memberikan medium bagi para penggunanya untuk terhubung melalui teknologi internet. Dalam hal tersebut Bigo Live telah menunjukan kemampuannya dengan memberikan fasilitas berupa fitur-fitur seperti komentar, chatting dan juga video call yang memungkinkan agar penggunanya dapat terhubung untuk membentuk jaringan pertemanan.
Dari hasil wawancara informan menjelaskan bahwa ia menggunakan Bigo Live ketika sedang bosan kemudian ada juga yang menggunakan Bigo Live untuk meluapkan emosi. Di Bigo Live ini rupanya informan mendapatkan hiburan dengan melakukan interaksi-interaksi dengan sesama pengguna lainnya. Interaksi ini membawa kesenangan bagi pengguna Bigo Live karena kebutuhannya terpenuhi.

Motif hiburan adalah motif yang berhubungan dengan dorongan individu untuk mencari hiburan, dorongan untuk melepaskan kejenuhan dan kebosanan, dorongan untuk mengisi waktu luang (McQuail, 1983:82). Pemenuhan kebutuhan hiburan ini didapatkan informan dengan mengunakan Bigo Live. Hal tersebut ditunjukan dengan adanya perilaku informan yang menggunakan Bigo Live ketika sedang bersantai dan untuk mengisi waktu luang. Ada juga informan yang mengatakan bahwa dengan berinteraksi menggunakan Bigo Live seperti halnya mendapatkan respon ketika ia melakukan broadcast ataupun dengan berbincang bercanda dengan temantemannya di Bigo Live ini membuat ia merasa terhibur dan akhirnya membuat ia mendapatkan kesenangan yang dibutuhkannya. 


\section{SIMPULAN}

Berdasarkan hasil penelitian yang telah dijelaskan sebelumnya, peneliti menarik kesimpulan bahwa motif yang mendorong penggunaan media sosial Bigo Live oleh mahasiswa jurusan Ilmu Komunikas Universitas Telkom ini relevan dengan teori motif penggunaan media yang diungkapkan oleh McQuail. Pertama motif informasi, dimana informan memiliki dorongan untuk mencari informasi mengenai Bigo Live yang merupakan media sosial baru serta penggunaan Bigo Live sebagai sarana pencarian informasi yang oleh informan menunjukan bahwa penggunaan Bigo Live ini didasari oleh adanya motif informasi dalam diri informan dan kebutuhan akan informasi tersebut kemudian terpenuhi dengan menggunakan Bigo Live. Kedua motif Identitas diri, dimana informan memiliki kebutuhan untuk menemukan dan mengidentifikasi diri sendiri. Ketiga adalah motif interaksi yaitu adanya keinginan dalam diri informan untuk menjalin interaksi sosial dengan individu lainnya dengan menggunakan perantara media sosial Bigo Live. Bigo Live memenuhi kebutuhan pengguna akan interaksi sosial dengan menyediakan fitur-fitur pendukung terjadinya interaksi seperti chatting, komentar, dan juga video call. Keempat yaitu motif hiburan, informan membutuhkan sarana penyaluran emosi serta untuk mengisi waktu luang diama dalam hal ini informan mengatasi kejenuhan dan rasa bosan deengan menggunakan Bigo Live di sela-sela aktivitasnya serta melakukan interaksi yang dapat memberikan kesenangan bagi dirinya dan orang lain dengan menggunakan Bigo Live. Keempat motif tersebut tidak semuanya dimiliki informan, motif yang paling sering ditemukan adalah motif informasi, interaksi dan hiburan.

\section{DAFTAR PUSTAKA}

Effendy, Uchjana Onong. 2003. Ilmu, Teori dan Filsafat Komunikasi. Bandung: PT Remaja Rosdakarya.

Ibrahim. 2015. Metode Penelitian Kualitatif: Panduan Penelitian Beserta Contoh Proposal Kualitatif. Bandung: Penerbit Alfabeta

Idrus, Muhammad. 2009. Metode Penelitian Ilmu Sosial. Jakarta: Penerbit Erlangga.

Maryati, \& Suryawati. 2003. Sosiologi 1. Jakarta : Erlangga.

McQuail, Dennis. 1983. Mass communication, theory, an introduction. California: Sage Publication.

1987. Teori komunikasi massa : Suatu Pengantar. Jakarta : Penerbit Erlangga.

Moleong, Lexy J. 2014. Metodologi Penelitian Kualitatif. Bandung : PT Remaja Rosdakarya.

Morissan. 2010. Manajemen Public Relations, Strategi Menjadi Humas Profesional.Jakarta: Kencana Prenada Media Group.

Nasrullah, Rulli. 2014. Teori dan Riset Media Siber (Cybermedia). Jakarta: Kencana Prenada Media Group.

2015. Media Sosial: Perspektif Komunikasi, Budaya dan Sosioteknologi. Bandung: Simbiosa Rekatama Media. 
Nurjaman, Kadar dan Umam, Khaerul. 2012. Komunikasi \& Public Relations. Bandung:CV Pustaka Setia.

Pujileksono. 2015. Metode Penelitian Komunikasi Kualitatif. Malang : Intrans Publishing

Rosabel, Deborah. (2016). Special Reports: Digital in 2016. Diakses dari https://wearesocial.com/sg/specialreports/digital-2016

Senova, A. 2016. Literasi Media sebagai Strategi Komunikasi Tim Sukses Relawan

Pemenangan Pemilihan Presiden Jokowi JK di Bandung. Jurnal Kajian

Komunikasi. Bandung: Universitas Padjadjaran. Diakses dari http://jurnal.unpad.ac.id/jkk/article/vie $w / 7411 / 5323$

Stuart, G.W. dan Sundeen, S.J. (1991). Principles and Practice of. Psychiatric Nursing. St. Louis: Mosby Company.

Sukmadinata, Nana Syaodih. 2013. Metode Penelitian Pendidikan. Bandung : PT Remaja Rosdakarya.

Tsana. (2016). Apa yang membuat Bigo LIVE begitu popular?. Diakses dari https://www.merdeka.com/peristiwa/ap a-yang-membuat-bigo-live-begitupopular.html

Widiartanto, Y.H. (2016). Pengguna Internet di Indonesia Capai 132 Juta. Diakses darihttp://tekno.kompas.com/read/2016 /10/24/15064727/2016.pengguna.inter net.di.indonesia.capai.132.juta 